Sign Systems Studies 29.1, 2001

\title{
Towards a semiotic definition of trash
}

\author{
Riste Keskpaik \\ Department of Semiotics, University of Tartu \\ Tiigi St. 78, 50410 Tartu, Estonia \\ e-mail: riste@ut.ee
}

\begin{abstract}
The phenomenon of trash has rarely been addressed in the cultural theoretical literature. However, its structural similarity with the concept of taboo as well as its role in the dynamics of culture has been stated. Current paper aims to summarize the partial contributions that have been made so far, localize them in a larger semiotic framework, and deriving from Lotman's approach to culture suggest a few further ideas for a semiotic definition of trash. It is proposed to define trash as a phenomenon marking the boundary between culture and non-culture/nature. In the context of the deepening environmental crisis (to which accumulation of trash contributes) a semiotic approach opens a new perspective for identifying the origin of the problem in our mind/culture rather than in nature.
\end{abstract}

Human discards ${ }^{1}$ can tell about the habits and belief systems of those who have left them behind and may even give evidence of the whole of a human culture. Nevertheless, the study of this domain has so far remained rather undiscovered by semioticians. Have we been blinded by cultural norms that prescribe the rejection of the phenomenon, or has the topic simply gone unnoticed because of a lack of relevant theory? Only recently, scholars of culture have begun to give some attention to the creative potential inherent in trash.

1 The English language offers synonyms such as 'rubbish', 'refuse', 'garbage', 'trash' etc. to designate human discards. The terminology of the scholars in this field of study varies. Douglas (1984) deals with 'dirt', Rathje and Murphy (1993) prefer the term 'garbage', while Artigiani (1994) uses 'trash' as the topic of his paper. I have chosen to employ 'trash' since it refers to human discards most generally and can be used in both the literal and a metaphoric sense. 


\section{Riste Keskpaik}

In 1973, a research project was launched by the University of Arizona to obtain practical information and data concerning human behaviour in relation to garbage (Rathje, Murphy 1993). The scholars proceeded by archaeological methods, sorting out people's discards and doing excavation in landfills with the aim to find out whether "it would be possible to investigate human behaviour 'from the back end" (Rathje, Murphy 1993: 14). The approach proved to be fruitful and led to valuable insights concerning several patterns of cultural behaviour well supported by empirical results. The Arizona Garbage Project has provided detailed data concerning consumer habits, landfill situations, biodegradation, and the recycling of trash.

Unlike the Arizona garbologists who believe that "to understand garbage you have to touch it, to feel it, to sort it, to smell it" (Rathje, Murphy 1993: 9), other scholars have attempted to "sift through the trash" without getting their hands dirty. A collection of such approaches can be found in a special issue of the American Journal of Semiotics (vol. 11(1/2), 1994) on the semiotics of trash. According to Adams (1994: 64), the volume is an assortment of the authors" "residues of intellectual endeavours". These semioticians of trash have investigated various examples and aspects of (d)evaluative processes in culture and society and have focused on the metaphorical usage of the concept of trash (Afable 1994, Anderson 1994, Bogumil 1994, Schofield 1994). Several theoretical frameworks have been adopted. Dickson (1994), Miller and Sotirin (1994), and Passariello (1994) follow the structural approach to trash elaborated by the anthropologist Mary Douglas (1984). From quite different perspectives, Artigiani (1994) departs from information theory and the theory of open systems (as developed by I. Prigogine) to describe some positive aspects of trash in the life and development of culture. Both structural and dynamic aspects are in the focus of the contribution by Adams (1994), who defines trash above all as a semiotic phenomenon and states that the problems associated with it require semiotic solutions. ${ }^{2}$

Our brief review of semiotic approaches to trash focuses on the following questions: In what context does trash become an object for semiotic analysis? How is the theoretical construct of trash connected to our everyday understanding of it? What is the role of trash in and for culture? Does trash belong to nature or to culture? Based on Lotman's theory of the semiosphere (Lotman 1990, 1992), a broader

\footnotetext{
${ }^{2}$ In addition to the studies discussed in this paper, other papers dealing with some semiotic aspects of trash are Bock and Zafirov (1992) or Posner (2000).
} 
theoretical framework will be proposed and its potential for ecosemiotics will be investigated.

\section{Trash in the framework of structural anthropology}

According to Lévi-Strauss (1963), human beings structure their world in the same way in which they categorize their language. The categories of the human mind are based on the principles of binary opposition. Human culture constitutes an integrated system that symbolically represents the order of the world. This symbolic system is also a practical tool for the orientation of humans in their world and for their operation in society.

However, as Leach (1966) and Douglas (1984) have shown, no matter how elaborated or differentiated the system of categories may be, there are always phenomena that defy categorization, and such phenomena acquire special status in culture. According to Leach, in our cultural perception of the world, we distinguish between "things" and "non-things":

I postulate that the physical and social environment of a young child is perceived as a continuum. It does not contain any intrinsically separate 'things'. The child, in due course, is taught to impose upon this environment a kind of discriminating grid which serves to distinguish the world as being composed of a large number of separate things, each labeled with a name. [...]

Now if each individual has to learn to construct his own environment in this way, it is crucially important that the basic discriminations should be clear-cut and unambiguous. There must be absolutely no doubt between me and $i t$, or between we and they. [...] We achieve this [...] kind of perception by means of simultaneous use of language and taboo. Language gives us the names to distinguish the things; taboo inhibits the recognition of those parts of the continuum which separate the things. (Leach 1966: 34-35)

An example of a "non-thing", according to Leach, is bodily excrement. Excrements threaten the fundamental distinction between me and not me and this is why they are tabooed in all cultures (see also Dickson 1994). However, in spite of their status of non-things, these substances are not only "felt to be dirty - they are powerful; throughout the world it is precisely such substances that are the prime ingredients of magical "medicines"" (Leach 1966: 38; on power and sacredness of bodily remnants see further: Passariello 1994). Hence, ambiguous elements are not only culturally suppressed, they are also vested with supernatural powers. 
Rituals, prohibitions, and detailed cultural rules concerning religious pollution and purification have been investigated by Mary Douglas. Douglas has shown that cleanliness is a matter of serious concern in culture. She argues that there is no essential difference between the traditional conception of religious pollution and contemporary ideas about trash: both aim at creating and maintaining order in human experience. Her conclusion is that there is a conceptual continuity between reactions to dirt and reactions to ambiguity or anomaly (Douglas 1984: 5). As these phenomena testify to the artificial nature of the system of categorization established by culture and pose a constant threat to its (symbolic) order, the question of trash is intimately tied to the origin of culture.

According to Douglas (1984: 35), "dirt is the by-product of a systematic ordering and classification of matter, in so far as ordering involves rejecting inappropriate elements". Trash is hence conceived of as a "residual category" of "rejected" things that do not conform to other categories. Furthermore, it also consists of dangerous things that are better to be avoided if not totally eliminated. Although trash is always determined by specific cultural order, it is as such a universal category.

The cultural categories of trash and pollution are hence genuinely linked to creating order, as Douglas (1984) has shown, and since order is always subject to corruption, the elimination or even total ignorance of trash is impossible. We are constantly faced with trash, as we are incessantly engaged in creating order out of chaos. Creating order means creating trash at the same time, so that trash and order are like two sides of one and the same coin. This conveys trash a positive function in culture. Trash establishes boundaries and confirms the categories that it does not conform to. Trash evinces a dynamics that does not lead to destruction, but also to creativity. It can even become a mediator between humans and supernatural powers (Passariello 1994). Trash is a resource out of which something new can be created. Its merit as an "apt symbol of creative formlessness" (Douglas 1984: 161) has most authentically been expressed in creation myths that interpret the origin of the world from dirt, mud, or even from "primordial defecation" (Dickson 1994: 165). 


\section{Role of trash in the dynamics of culture}

Although Mary Douglas has emphasized that trash plays an important role in the dynamics of culture, her model of structural anthropology cannot adequately cope with the dynamical aspects of the phenomenon. Models to cope with these aspects have been derived from the theory of complex dynamical systems, especially Prigogine's theory of dissipative structures.

In terms of the theory of entropy, Artigiani interprets trash as having "both thermodynamic and informational meanings". ${ }^{3}$ With reference to the Second Law of thermodynamics, the author argues that there are both negative and positive connotations if trash is accounted for in terms of entropy. Using the American Constitutional history as a test case, he tries to establish a link between trash and social evolution (Artigiani 1994: 249-250). Based on Prigogine's theory of dissipative structures, Artigiani describes society as an open system that unlike closed systems freely exploits resources from the external environment and manages to keep the local level of entropy low by expelling its waste to its environment. As Prigogine has demonstrated, there is a close relation between entropy and evolution, since "systems can evolve to greater levels of complexity by increasing their rates of external entropy production" (Artigiani 1994: 251). In information theoretical terms, it can be said that "one way in which open systems can become more complex, i.e., communicate more information about an expanded fraction of the world, is by incorporating "noise" from outside the system" (ibid.).

Open systems and their environments are in a relationship of reciprocal influence. The viability and development of a social system depend on the ability of this system to adapt to changes in its environment, to extend its frontiers, and to incorporate elements from its environment, which transform its inner structure. Such incorporation of elements from the environment lead to an increase in the level of the entropy produced by the social system. This model of social dynamics can be applied to interpret the social evolution of the United States of America: Artigiani describes the role of the US Constitution as its or-

\footnotetext{
3 "In thermodynamic terms, entropy refers to degraded energy, to energy which can no longer be accessed by a system. In informational terms, entropy refers to 'noise', to some flow across a boundary that cannot be processed by a system" (Artigiani 1994: 249).
} 


\section{Riste Keskpaik}

ganizing principle. Instead of prescribing all possible violations and specifying all necessary countermeasures, the Founders of the Constitution set up very general procedural rules. Their strategy was successful in maintaining the social system adaptable to changes and innovations in the social environment which the Founders themselves were still unable to foresee:

Societal perturbations are 'noise' communicated by individuals or groups an established politico-economic structure ignored and/or mistreated. They were people - like Blacks, women, or the urban poor - that were 'trash' from the perspective of existing society. For them to force their way into conventionally constituted social structures would have meant the destruction of those systems. But the new procedures for organizing societies introduced by the U.S. Constitution have the unexpected benefit of preserving order amidst the entropy bursts of societal transitions. Thus, the society can generate out of its internal fluctuations arrangements that represent more complex forms of selforganization by turning noise into information. (Artigiani 1994: 254-255)

This interpretation is not concerned with what trash as such is, but with how trash may become an integral part of a social system in the course of its evolution. However, Artigiani fails to distinguish between trash as something produced and considered to be external to the system and trash as a resource that may be incorporated or assimilated by the system. If everything that is external to the system is accounted for as "trash", the essential difference between trash as "refuse" and trash as a "resource" cannot be understood.

Artigiani's systems theoretical approach to trash has affinities with Lotman's theory of the semiosphere (Lotman 1990, 1992). ${ }^{4}$ This model gives a better account of the process of the incorporation of elements from the environment within a semiotic system. Culture in general as well as any specific culture can be considered as an independent semiosphere. The inside of this semiosphere is so organized that the texts considered to be more important from the point of view of the culture's self-description comprise the centre, while the less important texts remain at its periphery. The principles of organizing

${ }^{4}$ The semiosphere, according to Lotman $(1990 ; 1992)$ is the model of a dynamic view of cultural processes: "By analogy with the biosphere (Vernadsky's concept) we could talk of a semiosphere, which we shall define as the semiotic space necessary for the existence and functioning of languages..." (Lotman 1990: 123). The semiosphere can be compared with an individual subject defined by its external boundary which separates its "inside" from its "outside" having its own subjective "sense of self". Although it can be described as a hierarchically organized system, the semiosphere resembles more to a living organism than a stable structure. 
the internal space of a semiosphere remain stable, while the structures themselves are in constant motion: marginal structures gain prestige and attract supporters until they are recognized as central to the culture and finally become, in their turn, replaced by other peripheral structures (cf. Lotman 1990: 123-142; 1992: 16-18). In addition to the permanent flux of structures within the semiosphere there is a constant twofold flow over the external boundaries of the semiosphere:

The boundary is a mechanism for translating texts of an alien semiotics into 'our' language. It is the place where what is 'external' is transformed into what is 'internal', it is a filtering membrane which so transforms foreign texts that they become part of the semiosphere's internal semiotics while still retaining their own characteristics. (Lotman 1990: 136-137)

Cultural borders are "the hottest spots for semioticizing processes", since they are the place of "constant invasions from outside" (Lotman 1990: 136, 141). The dynamics in culture is achieved by two processes, structural drift within the semiosphere and permanent translation from without into the semiosphere. The concept of "translation" suggests that something previously considered as external, is then included in the cultural repertoire and related to the other elements of this culture. Translation also occurs between different codes within the semiosphere.

From this perspective, the production of trash can be considered as a translation mechanism. By calling certain cultural objects "trash" these objects attain the meaning of "things that are displaced and need to be removed". The objects lose their identities and become reduced to the category of trash (Douglas 1984: 160-161). Deprived of their "meanings", they are pushed towards cultural periphery. Such a "translation" is a dynamic process since it brings "trash" to the periphery of culture. From the centre of the culture the periphery and the exterior appear as "trash", at least on an evaluative level.

A further original semiotic definition of trash has been proposed by Adams (1994). The author describes three successive phases in dealing with trash. In every new phase, expenditure of additional energy and time is required. In the first phase, "people discard, ignore, or otherwise suppress trash" (Adams 1994: 66). In getting rid of worthless things as little energy as possible should be spent.

The second phase occurs when the cumulation of trash makes it a source of confusion. "People want to continue ignoring 'it', but they cannot because they must do something about "it" (Adams 1994: 66). The cultural resolution of this predicament is in the development of 
rituals, such as the ones dealing with social minority groups or the practices of sacralizing or tabooing certain phenomena of trash (like human excrements). In this context, it would also be interesting to examine to which extent our routine practices of cleaning and getting rid of refuse are rituals, and to see how such rituals have strengthened our belief that we are keeping trash under control. Of course, ritualization cannot be a definitive solution to the problem of the accumulation of trash, but

these rituals compel us to acknowledge that we create refuse; concurrently, they allow us to ignore this fact. Thus, trash becomes a part of culture, but continues to be an ephemeral part of culture [...] The ritualization of trash disposal will work until another externality makes this course of action no longer possible. People then make trash an integral part of their culture. To do so they have to refer to the higher frame of reference (Adams 1994: 66).

According to Adams, the solution of the problem of trash is a semiotic one. To cope with trash, a new sign has to be created and promulgated. This is an effort requiring expenditure of large amounts of time, energy, and money. Since people are always reluctant to change their habits and ways of thinking, they will be even more so if the proposed new ways cost time and energy. This is the key to the problem. From the systems theoretical perspective, culture, like any other living system, is unable to grow or even exist without continuously adapting to its internal and environmental changes, without integrating and translating "noise", and without time and energy.

\section{A semiotic definition of trash}

Most theories of trash have appeared as by-products of other theories. Meanwhile, however, the issue requires a definition of its own. Analyses of trash have so far remained incomplete since they have been restricted to only some features of the phenomenon. The definitions are much indebted to the theoretical framework in which they have been developed. Since no comprehensive theory of trash can be discerned as yet, it must suffice to summarize the partial contributions that have been made so far, localize them in a larger semiotic framework, and suggest a few further ideas for a better understanding of the phenomenon.

The models discussed so far do not sufficiently take into consideration how we perceive trash in our daily life. Trash is a cultural univer- 
sal. It is due to the fact that cultures, either as homeostatic systems or symbolic structures, need to get rid of the residues that endanger their existence. The kinds of objects discarded are culture specific. ${ }^{5}$ Discarding things is a process in the course of which things are physically relocated. By calling something "trash", its semiotic status is changed. The object becomes semiotically "relocated". When discarded, things cease to exist for the members of a culture. They are purposefully forgotten and are believed to have been pushed beyond the "outer edge" of culture. According to Lotman, objects which are considered as belonging to the non-semiotic world from the centre of a culture may, from outside of this culture, appear as belonging to the periphery of the same culture. So, the border of a given culture is determined by the position of the observer (Lotman 1992). Concurrently, whether trash is treated as a part of culture or not depends on who is judging. The garbologists, for example, treat trash as a part of culture. To them, landfills appear as "valuable lodes of information that may [...] produce valuable insights [...] into the nature of our own [society]" (Rathje, Murphy 1993: 4). Quite the same intuition comes to our mind when we run into trash in a naturally wild environment.

It is most appropriate to treat trash as a phenomenon marking the external boundary of culture. As the boundary "belongs to both contiguous semiospheres" (Lotman 1990: 136), it is possible to treat trash as belonging both to culture and to non-culture at the same time. It has also been shown that the boundary of the semiosphere functions as a translation filter: what is beyond has to be "translated" into the "language" of the semiosphere. Anything that crosses that boundary in either direction will be perceived as trash. On the one hand, by calling things "trash", they are (symbolically) excluded from culture, on the other hand, that what lies beyond has in general no positive value in this culture and appears just as "trash". It is interesting to notice that not only symbolically, but also physically, trash tends to be deposited at the periphery of the inhabited territory in uninhabitable areas where it appears as the last boundary post of culture, gradually fusing with nature.

Trash is a phenomenon blurring the boundaries between both culture and nature. For centuries people have expelled their waste into nature, and a considerable amount of it has vanished. This has sup-

\footnotetext{
${ }^{5}$ Moreover, trash is not simply a cultural universal, but all living organisms need to get rid of the remainders of their metabolism. This aspect, however is not discussed in the present paper.
} 


\section{Riste Keskpaik}

ported the idea of trash as a phenomenon opposed to culture. However, the problems that our culture faces today in connection with the accumulation of trash, hazardous waste, and the pollution of natural resources are overruling such an attitude. "Ecological knowledge is not sufficient to understand or solve the ecological problems which humans face, since these are consequences of certain deeply semiotic and cultural processes, intertwined with ecological and biological ones" (Kull 1998: 366). Consequently, the semiotic definition of trash as a border phenomenon of culture is a step towards the ecosemiotics, ${ }^{6}$ which "seems to be the possibility for facing these most important, and most difficult challenges of the contemporary world" (Kull 1998: 366).

\section{Conclusions}

From the point of view of cultural theory, approaches to the study of trash derive from two major theoretical traditions, structural anthropology and dynamical systems theory. In the structural anthropological perspective, trash appears as a category of things which threaten the culture and are therefore tabooed, but also the positive aspects of trash have been recognized in this framework, in particular its role as a source of cultural innovation. From the perspective of dynamical systems theory, it has been argued that trash is a phenomenon of the dynamics of culture. Treating trash in terms of entropy Artigiani has argued that the development and existence of a social system depends on its ability to get rid of its waste material as well as on its ability of incorporating it. The definition of trash in the framework of Lotman's theory of the semiosphere takes both structural and dynamical aspects of trash into consideration. Trash in this context can be defined as a phenomenon marking the boundary between culture and non-culture (nature). Such a definition of trash opens an ecosemiotic perspective. It may be a step towards a practical solution of the environmental problems connected with trash and pollution.

${ }^{6}$ The field and subject of ecosemiotics have been discussed in Nöth 1998, Kull 1998, Nöth and Kull 2000. 


\section{References}

Adams, Walter Randolph 1994. Sifting through the trash. The American Journal of Semiotics 11(1/2): 63-87.

Afable, Andy 1994. The cost of scavenging - A cautionary ethnographic tale. American Journal of Semiotics 11(1/2): 89-96.

Anderson, Myrdene 1994. Trashing and hoarding in words, deeds, and memory: A sampler from the Fourth World Saami. American Journal of Semiotics 11(1/2): 277-289.

Artigiani, Robert 1994. Send me your refuse: The U.S. Constitution as trash collector. American Journal of Semiotics 11(1/2): 249-276.

Bock, Herbert; Zafirov, Boge 1992. Der sprachliche Umgang mit Müll und Abfall: Eine zeichenbezogene Untersuchung von Presseberichten. Zeitschrift für Semiotik 14(3): 271-286.

Bogumil, Mary L. 1994. Voice, dialogue, and community: In search of the 'Other' in African American texts. American Journal of Semiotics 11(1/2): 181-196.

Dickson, Keith M. 1994. Ritual semiosis - Mumbojumbo: Magic, language, semiotic dirt. American Journal of Semiotics 11(1/2): 151-172.

Douglas, Mary 1984. Purity and Danger: An Analysis of the Concepts of Pollution and Taboo. London: ARK Paperbacks.

Kull, Kalevi 1998. Semiotic ecology: Different natures in the semiosphere. Sign Systems Studies 26: 344-369.

Leach, Edmund 1966. Anthropological aspects of language: Animal categories and verbal abuse. In: Lenneberg, Eric H. (ed.), New Directions in the Study of Language Cambridge, Mass.: The M.I.T. Press, 23-63.

Lévi-Strauss, Claude 1963. Structural Anthropology. New York: Basic Books.

Lotman, Yuri M. 1990. Universe of the Mind: A Semiotic Theory of Culture. London: Tauris.

- 1992. O semiosfere. In: Lotman, Y., Izbrannye stati: Stati po semiotike i tipologii kultury, vol. 1. Tallinn: Aleksandra, 11-24.

Nöth, Winfried 1998. Ecosemiotics. Sign Systems Studies 26: 332-343.

Nöth, Winfried; Kull, Kalevi 2000. Discovering ecosemiotics. Sign Systems Studies 28: 421-424.

Passariello, Phyllis 1994. Sacred waste: Human body parts as universal sacraments. American Journal of Semiotics 11(1/2): 109-127.

Posner, Roland 2000. Semiotic pollution: Deliberations towards an ecology of signs. Sign Systems Studies 28: 290-308.

Rathje, William; Murphy, Cullen 1993. Rubbish! The Archaeology of Garbage. New York: Harper Perennial.

Schofield, Mary Ann 1994. 'Rubble women': The clean-up crew of World War II. American Journal of Semiotics 11(1/2): 129-149.

Sotirin, Patricia J.; Miller, David J. 1994. Pink-collar trash: A critical semiotic analysis of the secretarial position. American Journal of Semiotics 11(1/2): 215-235. 


\section{О семиотической дефиниции мусора}

В литературе по теории культуры редко рассматривается такое явление как "мусор". В структуральной антропологии подчеркивается связь мусора и табу, мимоходом говорится и о роли мусора в динамике культуры. В данной статье дается обзор имеющихся культурологических взглядов на мусор в контексте семиотики. Исходя из теоретических положений Ю.Лотмана предлагется возможность рассматривать мусор как явление, маркирующее границу между культурой и некультурой. На фоне усугубляющегося экологического кризиса (одним аспектом которого является и аккумуляция мусора) существенной оказывается возможность показать сквозь призму семиотики, что проблема заключается не в природе, а в нашем сознании/культуре.

\section{Prügi semiootilisest defineerimisest}

Kultuuriteoreetilises kirjanduses on harva põhjalikumalt käsitletud sellist nähtust nagu prügi. Strukturaalantropoloogias on välja toodud prügi sarnasus tabuga. Põgusalt on juttu olnud ka prügi rollist kultuuri dünaamikas. Käesolevas artiklis antakse ülevaade olemasolevatest kultuuriteoreetilistest lähenemistest prügile semiootika kontekstis. J. Lotmani teoreetilistest seisukohtadest lähtuvalt pakutakse välja võimalus käsitleda prügi kultuuri ja mittekultuuri/looduse piiri markeeriva nähtusena. Süveneva ökoloogilise kriisi taustal (mille üheks aspektiks on ka prügi akumuleerumine) osutub oluliseks võimalus semiootilise lähenemise kaudu näidata, et probleem ei peitu mitte looduses vaid meie teadvuses/kultuuris. 